\title{
If Democracies Need Informed Voters, How Can They Thrive While Expanding Enfranchisement?
}

\section{Citation}

Hochschild, Jennifer L. 2010. If democracies need informed voters, how can they thrive while expanding enfranchisement? Election Law Journal: Rules, Politics, and Policy 9(2): 111-123.

\section{Published Version}

doi:10.1089/elj.2009.0055

\section{Permanent link}

http://nrs.harvard.edu/urn-3:HUL.InstRepos:8965557

\section{Terms of Use}

This article was downloaded from Harvard University's DASH repository, and is made available under the terms and conditions applicable to Open Access Policy Articles, as set forth at http:// nrs.harvard.edu/urn-3:HUL.InstRepos:dash.current.terms-of-use\#OAP

\section{Share Your Story}

The Harvard community has made this article openly available.

Please share how this access benefits you. Submit a story.

Accessibility 


\title{
If Democracies Need Informed Voters, How Can They Thrive While Expanding Enfranchisement? JENNIFER L. HOCHSCHILD* Election Law Journal: Rules, Politics, and Policy 9 (2), June 2010: 111-123
}

\begin{abstract}
Three uncontroversial points sum to a paradox: 1) Almost every democratic theorist or democratic political actor sees an informed electorate as essential to good democratic practice. Citizens need to know who or what they are choosing and why - hence urgent calls for expansive and publicly funded education, and rights to free speech, assembly, press, and movement. 2) In most if not all democratic polities, the proportion of the population granted the suffrage has consistently expanded, and seldom contracted, over the past two centuries. Most observers, and I, agree that expanding enfranchisement makes a state more democratic. 3) Most expansions of the suffrage bring in, on average, people who are less politically informed or less broadly educated than those already eligible to vote.

Putting these three uncontroversial points together leads to the conclusion that as democracies become more democratic, their decision-making processes become of lower quality in terms of cognitive processing of issues and candidate choice. The paradox is both historical why have democracies expanded the franchise to include relatively ignorant voters? - and normative - why should democracies expand the franchise to include relatively ignorant voters?

The article addresses both questions. First, I review the historical trajectory of democratization in the United States (although the argument is not specific to that country). I then describe plausible empirical explanations for the paradox: voters are not really that ignorant; the United States is not and never has been really a democracy; and institutions or electoral rules have been developed to substitute for voters' knowledge. I also analyze plausible normative explanations for the paradox: democracy does not, or does not primarily, need cognitively sophisticated citizens; and democracy offers benefits that outweigh the deficits of citizens' lack of knowledge. I offer a few reflections on both sets of explanations, but cannot genuinely dissolve the paradox.
\end{abstract}

\footnotetext{
* Jennifer L. Hochschild is the Henry LaBarre Jayne Professor of Government at Harvard University. Many people gave useful comments; she thanks C. Anthony Broh, Katherine Levine, Sanford Levinson, David Mayhew, Cindy Rosenthal, an anonymous reviewer, the editors of Election Law Journal, and participants in seminars at the American Political Science Association's 2009 annual convention and at the Julian J. Rothbaum Distinguished Lecture Series at the University of Oklahoma, 2007.
} 
In a democracy, knowledge is power.

-- (Jerit et al. 2006): 266

The two simplest truths I know about the distribution of political information in modern electorates are that the mean is low and the variance high.

-- (Converse 1990): 372

If a nation expects to be ignorant and free, in a state of civilization, it expects what never was and never will be.

-- Thomas Jefferson, letter to Charles Yancey, 1816

in (Jefferson 1903-04): v. 14, p. 384

Ever since the idea of democracy became an aspiration rather than a fear or threat, political actors have argued that citizens must be knowledgeable for it to function well. Aristotle sought to avoid democracy, largely on the grounds of popular ignorance: "What are the matters over which... the general body of citizens... should properly exercise sovereignty? It... is dangerous for men of this sort to share in the highest offices, as injustice may lead them into wrongdoing, and thoughtlessness into error" (Aristotle 1946: 124). Several millennia later, American radicals agreed with the diagnosis, but proposed a different solution. Thomas Jefferson prescribed "two great measures,... without which no republic can maintain itself in strength: 1 . That of general education, to enable every man to judge for himself what will secure or endanger his freedom. 2. To divide every county ... [so] that all the children of each will be within reach of a central school in it" (Thomas Jefferson to John Tyler, 1810, in (Jefferson 1903-04), v. 12, p. 393). Benjamin Franklin agreed: "Nothing can more effectually contribute to the Cultivation and Improvement of a Country, the Wisdom, Riches, and Strength, Virtue and Piety, the Welfare and Happiness of a People, than a proper Education of youth" (Franklin 1962 [1749]: 152-153).

Political scientists concur that a knowledgeable citizenry is necessary for effective and gratifying democratic governance. As Michael Delli Carpini and Scott Keeter put it in the most authoritative study of the subject,

Factual knowledge about politics is a critical component of citizenship, one that is essential if citizens are to discern their real interests and take effective advantage of the civic opportunities afforded them.... Knowledge is a keystone to other civic requisites. In the absence of adequate information neither passion nor reason is likely to lead to decisions that reflect the real interests of the public. And democratic principles must be understood to be accepted and acted on in any meaningful way (Delli Carpini and Keeter 1996): 3, 5).

I agree, at least in principle, and so do most others who have thought about this issue. ${ }^{1}$ Political scientists have, however, made it painfully clear just how much knowledge citizens lack. Fewer than one third of high school students know that the Civil War occurred in the half-century of 1850 to 1900, and only two-thirds can find France on a map (Ravitch and Finn 1988). "In a

\footnotetext{
${ }^{1}$ Michael Schudson appears to disagree somewhat: "In popular political discourse, there is too literal an appeal to Progressive ideals of the informed citizen and too rarely an appreciation of the rights-regarding citizen" (Schudson 1998): 308). He retracts a lot of the disagreement, however, in clarifying the point: "the model of the informed citizen... still holds a cherished place in our array of political values, as I think it should, but it requires some modification. ... I would propose that the obligation of citizens to know enough to participate intelligently in governmental affairs be understood as a monitorial obligation" rather than requiring deep or full knowledge of issues and actors, a.k.a. "a stale mugwumpery" (ibid., p. 310-311). That is quite close to most of the arguments in the rest of this article.
} 
random telephone survey of more than 2,000 adults, conducted by the Public Opinion Laboratory at Northern Illinois University, 21 percent of the respondents said they believed that the sun revolved around the earth; an additional 7 percent said they did not know which revolved around which" (Halpern 1997). A long list of studies shows that Americans in the 1950s thought the Bill of Rights was written recently by Communists, that 40 percent do not know the name of the vice president, that few can name their own Representative in Congress, that many believe that more of the federal budget goes to foreign aid than to social security, and so on. ${ }^{2}$ Many roads lead to the same conclusion, that we are a "dunce-cap nation," as Newsweek put it in 2007 (Braiker 2007).

I do not challenge the aspiration for a knowledgeable citizenry in a democracy - after all, I (like many readers) am a teacher of politics, and I want students in my classes to learn facts, concepts, and strategies for acquiring more information. Nor do I challenge the claim that Americans are ignorant of politically salient information, although the parlor game of "duncecap nation" can be exaggerated and mean-spirited. ${ }^{3}$ My purpose, in fact, is to dwell on and indeed emphasize the discrepancy between the aspiration for an educated citizenry in a democracy and the actual facts of democratic governance, at least in the United States. I do so by focusing on the paradox that every expansion of the franchise throughout American history has been understood to enhance democracy despite arguably reducing the politically-relevant knowledge of the median voter. I cannot explain the paradox away, but I conclude by offering some plausible reasons why Americans have maintained or even deepened it over the past two centuries. ${ }^{4}$

\section{Expansion of the Franchise in American History}

Most moves to enfranchise previously-excluded residents of the United States have been appropriately understood as increasing the democratic nature of the polity. But they have also lowered the average socioeconomic status and level of education of the population eligible to vote. That is, democratization has been operationalized largely as giving the vote to some subset of the disadvantaged or of others likely to know fewer social and political facts or concepts than current voters.

One could demonstrate this claim beginning with the colonial era, but here I focus on the period after most Americans decided they wanted a democratic polity - that is, in the decades following adoption of the Constitution. In the first half of the nineteenth century, all thirty-one states rewrote their constitutions. Almost all eliminated the property or tax requirement for voting. After an earlier restrictive period, most states outside of the northeast also extended the franchise to noncitizens by the middle of the nineteenth century. The proportion of eligible voters rose from somewhere between "one in thirty" Americans and two-thirds of adult white

${ }^{2}$ A sample of this extensive literature includes Luskin 1987; Ferejohn and Kuklinski 1990; (Zaller 1992); (Bennett 1996); (Gordon and Segura 1997; Kuklinski et al. 1997); (Lupia et al. 2000); (Gilens 2001); (Alvarez and Brehm 2002); and (Althaus 2003).

${ }^{3}$ As an example: in June 2008, Newsweek ran an article entitled, "Just How Low Will They Go?" with the subhead: "With 'elitist' a choice slur, candidates are trying to win over the new 'It' demographic: 'low-info voters'" (Smalley and Kliff 2008).

${ }^{4}$ An essential clarification: I do not oppose democracy or expansion of enfranchisement. I strongly endorse both, for reasons explicated below in the normative section of this article. I had hoped that this note would not be needed, but at least one reader has found my argument ambiguous enough on this point that clarification seemed warranted. 
men $^{5}$ in 1789 to almost all adult white men. In some states the number of voters doubled or tripled over a few decades.

Delegates to state constitutional conventions carefully considered whether a democratic polity requires educated citizens. Some proposed literacy tests for the suffrage, on the grounds that "persons wholly destitute of education do not possess sufficient intelligence to enable them to exercise the right of suffrage beneficially to the public." Such proposals were decisively defeated in the five states that considered them (Samuel Jones in (Keyssar 2000): 66; see also (Scalia 1999). Others proposed continuation of the rule that voters must own at least some property, on the grounds that "the theory of our constitution is, that extreme poverty... is inconsistent with independence. It therefore assumes a [property] qualification" (Josiah Quincy, in (Peterson 1966): 65). But this argument was answered by the claim that "if taking away this [property] qualification would weaken the moral force in the community, as had been urged, he [the speaker] should be for retaining it; but that force depends on education, and the diffusion of intelligence" (James T. Austin, in (Peterson 1966): 67). David Buel Jr. of New York summarized the reformers' views, which carried the day in most states:

The provision already made for the establishment of common schools, will, in a very few years, extend the benefit of education to all our citizens. The universal diffusion of information will forever distinguish our population from that of Europe. Virtue and intelligence are the true basis on which every republican government must rest. When these are lost, freedom will no longer exist. The diffusion of education is the only sure means of establishing these pillars of freedom. I rejoice in this view of the subject, that our common school fund will (if the report on the legislative department be adopted,) be consecrated by a constitutional provision; and I feel no apprehension, for myself, or my posterity, in confiding the right of suffrage to the great mass of such a population as I believe ours will always be (Peterson 1966): 203).

In short, a widely and publicly educated citizenry is both necessary and sufficient to sustain a broad-based democracy.

Expansion of democratic participation was not linear in the nineteenth century. New Jersey's legislature withdrew the franchise from propertied women. By 1850 legislators in all but five states or territories (where only four percent of the nation's free black population lived) had disfranchised propertied black men or denied them the right to vote when the territory achieved statehood. States thereby arguably removed voters from the rolls who were relatively more educated and knowledgeable about American politics, while adding those who were relatively less educated or politically knowledgeable. ${ }^{6}$

${ }^{5}$ The very disparate figures come from, respectively, (Bone and Ranney 1976): 35 and (Keyssar 2000): 24).

${ }^{6}$ Formal education, political knowledge, and political sophistication are not synonymous, and at one point later in the discussion I distinguish among them. For most of this article, however, I treat them as interchangeable. That generally suffices for my purposes since "a voluminous literature shows that socioeconomic factors, such as being rich or educated, are positively associated with political knowledge [citations deleted]. So well developed is this literature that the characteristics commonly associated with political knowledge are referred to as the 'usual suspects" " (Jerit et al. 2006): 266). For example, people with higher levels of education rank higher in each of six "knowledge domains" and know more about state and local as well as national politics (Delli Carpini and Keeter 1996: 143-150). They have other traits important for democracy as well: "the more educated citizen is more tolerant of the freedom of expression of unpopular political views, more knowledgeable of the fundamental principals (sic) of democracy, 
These are problematic moves from the perspective of the claim that a politically knowledgeable or well-educated citizenry is essential to democracy. After all, as of 1850 about 60 percent of white boys aged 5 to 19 were enrolled in school "for at least one day" a year (Goldin 2006): 2-431). Although a higher figure than in other western nations, that still excluded two-fifths of future voters. Adult men were presumably less well educated than children, since schooling was expanding during the early decades of the nineteenth century and adult male immigration from poor countries was rising. So expanding the franchise to all white men while withdrawing it from propertied women almost certainly diluted the median voter's literacy and political knowledge.

The Fifteenth Amendment of 1870 enfranchised an even more poorly-educated group of men, recently enslaved African Americans. As of 1870 not quite a tenth of black young men were in school, even by a measure of schooling for "at least one day a year" (Goldin 2006): 2431). Black adults had even less formal education. So the new voters' literacy was slight and their political knowledge, at least as conventionally measured, was slim.

After reversing the democratizing momentum by disfranchising almost all black men, the United States again moved in the opposite direction in the period leading up to 1920 by granting the vote to (white) women. This was perhaps the only occasion in American history in which expanding the franchise also increased, or at least did not decrease, the knowledge of the median voter. By 1900, 90 percent of women in the United States were literate in at least one language (Bose 2001): 166). And from 1900 on, the proportion of white females enrolled in school almost equaled that of white males (Goldin 2006): 2-431).

After World War II, however, the United States again moved to give voting rights to people likely to have relatively little schooling or conventional political knowledge. In 1944 the Supreme Court ruled against whites-only primaries, in Smith v. Allwright (321 U.S. 649, 1944). The poll tax was constitutionally banned for national elections in 1964 and for all elections two years later (in Harper v. Virginia State Board of Election [383 U.S. 663, 1966]). Those two decisions made it slightly easier for very poor people to vote. The Voting Rights Act of 1965, upheld in South Carolina v. Katzenbach (383 U.S. 1, 1966) and enforced by the Justice Department, began to reverse the disfranchisement of African Americans. In 1971 the Twentysixth Amendment gave voting rights to eighteen-year-olds.

Finally, in recent years many states have liberalized their laws regarding previously disfranchised felons. "Between 1997 and 2007, 18 states made progressive changes to their felony disfranchisement laws, enfranchising over 700,000 individuals. Three progressive measures passed in 2008, one legislative and two executive" (American Civil Liberties Union 2008). Laws or policies in some states (occasionally the same ones) have tightened restrictions on felons or ex-felons attempting to vote, but strongly punitive proposals have failed to pass state legislatures in recent years. Two public opinion polls in the early 2000s showed majority public support for at least partial re-enfranchisement of ex-felons, probationers, and parolees (Manza and Uggen 2004).

Incarcerated people are among the least well educated Americans. As of 1997, the most recent year reported by the federal government, 27 percent of federal prisoners, 40 percent of state prisoners, and fully 47 percent of people in local jails had not graduated from high school or attained a GED. That compares with 18 percent of the general population (not including

and maintains more information on other current political facts. ... Education [also] creates engaged citizens by cutting the cost of pursuing and protecting interests in politics" (Nie et al. 1996): 86, 59). 
probationers). ${ }^{7}$ Enfranchising ex-felons may be the right thing to do for many reasons, but among them is not enhancing the median voter's level of knowledge.

Even beyond the remaining ex-felons denied the right to vote, demands to expand the franchise may not yet have ended in the United States. As of 2000, the Empowerment Project was "a research project on registration and voting laws affecting people with disabilities," funded by the U.S. Department of Education and located at the University of Minnesota. Its self-determination philosophy calls for the active participation of people with intellectual and developmental disabilities in the civic life of their communities and country. They are being encouraged to help their preferred candidates run for office, communicate their opinions to elected officials, take part in disability advocacy organizations - and vote. At times, however, ... state law permits some individuals with intellectual and developmental disabilities to lose their right to vote because they have been adjudicated "mentally incompetent" or are under guardianship. These laws not only prevent them from voting, but present a powerful symbolic barrier to full citizenship for people with disabilities. ${ }^{8}$

The Empowerment Project sought to "underscore ... similarities [of laws in 44 states disfranchising adults under guardianship or conservatorship] to voting prohibitions based on gender, race, and other historically devalued statuses" - that is, the laws just described. In this view, exclusions for cognitive and emotional impairment "raise serious constitutional issues" (see also (Kohn 2008).

The paradox-democracy needs informed voters, but enfranchising ill-informed citizens is a democratizing move-has deep roots and wide applicability. It is more evident in many other polities than in the United States, because their citizens or residents are even more disadvantaged with regard to publicly-funded schooling, transportation, communication, access to independent media, and other mechanisms for attaining politically relevant knowledge. The paradox cannot be explained away, but perhaps it can be explained. I turn now to that task.

\section{How Has Democracy Learned to Thrive without an Educated Citizenry?}

Jefferson was apparently wrong in asserting that "if a nation expects to be ignorant and free, in a state of civilization, it expects what never was and never will be." Americans live in a relatively free and civilized democracy (or in a reasonably effective polyarchy, to use Robert Dahl's more cautious term (Dahl 1975), ${ }^{9}$ despite their considerable ignorance. How can that be?

Explanations fall into three categories: Americans are not really that ignorant; the United States is not really a democracy; institutions or electoral rules effectively replace the posited knowledgeable citizen. The first and third of these explanations can coexist, while the first (or third) and second are mutually contradictory. Even if analytically compatible, the explanations have very different political valences. Whether their relative merits can be tested remains to be seen.

Americans Are Not Really That Ignorant: The basic claim here is that the paradox rests on measurement error, either in the narrow sense that voters know more than specific indicators show or in the broader sense that any measurable indicator does not capture citizens' capacities for coherent self-governance. One version of the narrow argument is literally measurement error; for many years the canonical American National Election Studies (ANES) provided misleading

${ }^{7}$ http://www.albany.edu/sourcebook/pdf/t645.pdf

${ }^{8} \mathrm{http}: / /$ www.ici.umn.edu/products/archive/PRB/111/default.html

${ }^{9}$ A polyarchy is defined most succinctly as "a regime in which opportunities for public contestation are available to the great bulk of the population" (Dahl 1975): 202). Dahl also writes frequently of "the opportunities for effective participation" (e.g. p. 14). 
or incorrect information about open-ended responses to an important survey item on political knowledge. In 2008, the Principal Investigators for the ANES reported to the user community their recent discovery of multiple errors in recording and coding answers to open-ended political knowledge questions, and more importantly, an excessively narrow definition of a correct answer in a set of political knowledge questions. ${ }^{10}$ The misinformation is being corrected, measurement procedures are being made transparent, and scholars may "discover" that citizens have more relevant political knowledge than we had thought (Gibson and Caldeira 2009); see also (Mondak and Davis 2001). Others provide evidence showing that citizens know a lot about issues that are particularly salient to them (Hutchings 2003) or that their knowledge is obscured by survey questions couched in language appropriate to survey researchers but not to respondents themselves (Hochschild 1981). Some argue that if the media provide useful information, citizens can attain the political knowledge they need (Neuman et al. 1992); (Prior 2005); (Jerit et al. 2006).

The broader version of the claim that Americans are not really that ignorant addresses the ways that people can effectively use what information they have, even if that information is thin or they lack extensive schooling. This literature is extensive and well-known, so I will summarize it briefly: people may be efficient users of shortcuts or heuristics, knowing for example that Democrats stand for "the little man" or Republicans for "law and order." That is all the knowledge they need to vote for the right person to act on behalf of their broader and deeper interests (Popkin 1993). Alternatively, citizens may be Bayesian updaters; their attention to a recent event or phenomenon shapes their next political action, such as a vote (Bartels 1996). They have weak or even forgotten prior opinions about politics, but the phenomenon to which they now attend is roughly in keeping with what they would have known if they had remembered what they once knew - so they can act as though they retained that prior knowledge.

Or citizens take cues from elites whom they trust, so that they can act politically and vote as though they knew as much as those elites do. ${ }^{11}$ One variant of this view posits that elites do not create predispositions among voters but rather activate existing predispositions by providing certain types of information (Alvarez and Brehm 2002). Another variant proposes that political campaigns inform voters about "fundamental variables and their appropriate weights," so that individuals can vote according to their preferences (Gelman and King 1993): 433; see also (Wolak 2009). These arguments differ in important details, but all suggest that general ignorance need not imply political ignorance or incapacity.

The phrase "retrospective voting" captures another version of the argument that voters know roughly all that they need to know (Schumpeter 1942; Downs 1957; Fiorina 1981). Its key tenet is that voters only have to be able to judge whether they have gotten better off or worse off under the current political regime; if the former, they support the incumbents and if the latter they seek to vote the rascals out. This simple model can be complicated by asking whether voters make personal or sociotropic judgments (Kinder and Kiewiet 1979), by investigating the role of the media and other possible influences on one's judgment, by trying to determine if voters distinguish between calamities that were or were not the fault of the party in office, and so on (Somin 2004) and citations therein). But the basic claim is that citizens know enough to judge trajectories from the recent past even if they cannot make good decisions about the near future.

A more astringent version of this argument suggests that formal education and conventional political information are irrelevant to or even get in the way of "genuine" or

\footnotetext{
${ }^{10} \mathrm{http} / / /$ www.electionstudies.org/announce/newsltr/20080324PoliticalKnowledgeMemo.pdf

${ }^{11}$ For a good recent review see (Boudreau 2009a) or (Boudreau 2009b).
} 
"important" political knowledge. Racial, religious, or ideological minorities, for example, might attain politically relevant information from their own like-minded communities that would be undermined by too much mainstream formal schooling or political socialization (Woodson 1933). Not surprisingly, political scientists deeply immersed in the formal educational system are unlikely purveyors of such an argument. But it is a plausible, albeit more ideological, extension of the scholarly argument that citizens do not need schooling or conventional political knowledge to be effective political actors.

Yet another version of this response to the paradox holds that new voters may in fact lack knowledge and political sophistication, but they gain it with practice. John Stuart Mill is the chief spokesperson for this view. In Considerations on Representative Government, he argues over and over that "among the foremost benefits of free government" is "education of the intelligence and of the sentiments which is carried down to the very lowest ranks of the people when they are called to take a part in acts which directly affect the great interests of their country. ... [Readers are urged] to recognize a potent instrument of mental improvement in the exercise of political franchises by manual laborers" (Mill 1862): 170). I know of no compelling way to test this proposition, because of the fact of self-selection among new voters, the fact that many things change in the years after one attains the right to vote, and the lack of a counterfactual. Nevertheless, Mill's conviction persists. To give only one example, New York University's Brennan Center for Justice argues for restoring voting rights to all ex-felons partly on the grounds that "allowing voting after release from incarceration affirms the returning community member's value to the polity, encourages participation in civic life, and thus helps to rebuild the ties to fellow citizens that motivate law-abiding behavior." 12

Finally in this set of responses, perhaps the paradox does not hold because American voters really are, and have always been, well educated, at least compared with citizens of other would-be democratic polities. Tocqueville observed this fact with wonder at several points in Democracy in America: "I know of no other people who have founded so many schools or such efficient ones," or "it cannot be doubted that in the United States the instruction of the people powerfully contributes to support the democratic republic" (de Tocqueville 1966 (1848)): 83, 279). In the middle of the nineteenth century, roughly twice as many children were enrolled in elementary school in the United States as in every European country except Germany. By the turn of the twentieth century, when the largest European nations had caught up to the United States in early schooling, the United States began to move ahead on high schools (Easterlin 1981): Appendix table 1). As Claudia Goldin and Larry Katz point out, "when, during World War II, President Roosevelt formulated the GI Bill of Rights to fund college for millions of Americans, his counterpart in Great Britain, Prime Minister Churchill, was given a bill that granted youth the right to free secondary-school education" (Goldin and Katz 1997): 10-13; see also (Dewhurst et al. 1961): 315). By now, virtually all developed nations have caught up to or even passed the United States in secondary schooling, but Americans are still better educated than are residents of most other countries. Among G-8 countries, only Canada and the Russian Federation have a larger share of adults who have completed academic or vocational higher education (National Center For Education Statistics 2009): 67; see also (Barro and Lee 2001). The United States spends 6.7 percent of its GDP on education; the next highest countries are France and the United Kingdom at 5.3 and 5.2 percent respectively (National Center For Education Statistics 2009): 63). ${ }^{13}$

\footnotetext{
$12 \mathrm{http} / / / \mathrm{www}$. brennancenter.org/content/resource/restoring_the_right_to_vote/,p. 9

${ }^{13}$ Even in California's extreme budget crisis of 2008, when two-thirds of its voters preferred spending cuts rather than tax increases, only a quarter supported cuts in public school budgets
} 
The United States Is Not Really a Democracy: A contrasting explanation for the paradox -- that democracy needs informed voters but enfranchising ill-informed citizens is a democratizing move -- focuses on the term "democracy" rather than the term "informed voters." The basic claim addresses not measurement error but a category mistake. That is, in this view a democracy does need informed citizens; American citizens are ill-informed; the United States is not a democracy or even a polyarchy. The argument may include a causal link: "the United States is not a democracy because American citizens are ill-informed," or even "American citizens are illinformed because the United States is not a democracy."

Ironically, perhaps, this is the view closest to Jefferson's vision, but in a despairing rather than idealistic way. Since most citizens have always been and remain ill-informed, they have never been able to control their government and elites have always, intentionally or not, manipulated the purportedly democratic levers to their own advantage. The apparent democracy has been a sham - either always or since the Constitution replaced the Articles of Confederation - and it continues to be, despite Jefferson's endorsement.

A relatively mild version of this argument is that citizens are not so much ill-informed about policy or political choices as unable to connect their knowledge and values to the correct (from their viewpoint) policy or political choices. This is Larry Bartels' explanation for broad public support for President George W. Bush's regressive tax policies. For individuals to have been able to express their views according to their interests, they needed not only to perceive that economic inequality was rising and that they opposed such an increase, but also that the proposed tax cut would worsen inequality and harm their interests. That final link in the chain of political reasoning was lacking (Bartels 2008). Roughly the same point is entailed by the argument that politically unsophisticated citizens cannot use the heuristics celebrated by Popkin and others; "people take their heuristics off the shelf, use them unknowingly and automatically, and rarely worry about their accuracy. An inherent part of human nature, these broader, less discriminating sorts of heuristic generally trump strategic decision making" (Kuklinski and Quirk 2000); see also (Lau and Redlawsk 2001).

A stronger version of this argument is that elites deliberately keep citizens ignorant and allow voters to think, incorrectly, that they are actually making important choices of policies or leaders. Citizens may be flattered, provided with false or misleading information, or simply schooled poorly. The elites may be pursuing their economic interests as in a classic Marxist view of western democracy, gender or racial dominance as in Charles Mills' "epistemological contract" (Mills 1997), or a particular set of concerns appropriate to an interest group or regulated industry. The central point is that so long as citizens are poorly informed, the democratic form is largely or only a shell (Schattschneider 1960); (Parenti 2007).

In recent years, Michael Graetz and Ian Shapiro (Graetz and Shapiro 2005) as well as Jacob Hacker and Paul Pierson (Hacker and Pierson 2005) have written case studies supporting this view. Both sets of authors argue that Bush's proposed tax cuts in 2001 and 2003 were passed because elites deliberately manipulated and misrepresented factual knowledge so that even reasonably knowledgeable citizens could not express their true views. ${ }^{14}$ Graetz and Shapiro

and only three-tenths did so for higher education

http://www.field.com/fieldpollonline/subscribers/.

${ }^{14}$ Both Hacker and Pierson, and Bartels, perceive their respective explanations for the 2001 and 2003 tax cuts to contradict each other. The arguments certainly have different analytic and 
focus on interest groups and think tanks, while Hacker and Pierson focus on members of Congress, but both pairs of authors see a failure of democracy because of a lack of citizens' genuine knowledge. It was not their fault, just as ex-slaves' illiteracy was not their fault more than a century earlier. Nevertheless, in this view, Jefferson was right in pointing out that a nation cannot be both ignorant and free.

Institutions or Electoral Rules Effectively Replace the Posited Knowledgeable Citizen: A third way to address the paradox -- that a democracy needs informed citizens but democratizing reduces the average level of citizens' knowledge -- is to identify ways discovered by would-be democracies to work around it. The focus here is neither measurement error nor category mistake but rather unit of analysis. Up to this point, I have discussed citizens or voters and democratic governance as though there were a direct, unmediated relationship between the former and the latter. But that, of course, is not the case; an extensive set of institutional actors and electoral rules have grown up to intervene between voters and decision-makers.

In the view just analyzed, institutional actors and complex decision rules are part of the problem rather than part of the solution since they have kept voters uninformed or taken advantage of their lack of knowledge. But in this view, institutional actors or decision rules are part of the solution because they have largely substituted for citizens' knowledge or amplified what knowledge they hold in a way that promotes democratic governance.

Political parties may be one such institution. John Aldrich quotes E.E. Schattschneider as observing that "political parties created democracy, and... democracy is unthinkable save in terms of parties" (Schattschneider 1942): 1). Aldrich describes that view as "overstated," but substitutes a word almost as strong: "democracy is unworkable save in terms of parties.... The political party as a collective enterprise, organizing competition for the full range of offices, provides the only means for holding elected officials responsible for what they do collectively" (Aldrich 1995): 3). The media may be another institution that has learned to substitute for a knowledgeable citizenry in maintaining a functioning democracy (Street 2001); (Protess et al. 1987). Interest and advocacy groups pressure politicians toward particular policy stances and work hard to punish them for espousing the wrong ones; if these groups in fact represent the people for whom they claim to be advocating, then the people themselves can stay ignorant and still have their interests met (Meyer et al. 2005); (Berry and Wilcox 2007); (Dovi 2007); (Schlozman et al. 2008).

In yet another formulation, a small set of political activists is either generally knowledgeable about politics or particularly knowledgeable about particular aspects of politics. If the activists make their views known and influence political outcomes, and if their ranks are reasonably open to others with strong views, then they too can be effective stand-ins for a citizenry that would agree with the activists if its members held informed views (Dahl 1961). In the view of some analysts, the American judicial system has evolved to provide reasonably independent and nonpolitical courts that at crucial moments have provided ballast, coherence, and substantive considerations to an otherwise fragmented or nonrational democratic polity (Brace and Hall 2005); (Sunstein 2005). Or at least courts have been able to take some of the most contentious issues out of the overtly political arena, thereby buffering the electoral system for a while from the preferences of voters driven most by passion and least by reason (Hochschild 1984); (Whittington 2007).

Furthermore, according to this argument, electoral or decision rules can be designed to help maintain democracy despite citizens' ignorance. James Madison and other Constitutional

empirical emphases and may imply different reform proposals. But in my scheme they both fit into the general rubric of "the United States is not really a democracy." 
framers promoted large electoral districts and relatively few representatives so that only a small number of the best men would emerge as candidates. With that filter in place, voters could safely choose members of the House of Representatives. In their constitutional design, election of the president would similarly be safe if an electoral college, again comprised of wise and knowledgeable elite men, made the choice, and the choice of Senators could safely be entrusted to state legislators. A century later, lawmakers pursued the same strategy in a different arena by seeking to ensure that regulatory agencies and the Federal Reserve Board would be subject to, at most, indirect electoral control. Political scientists and activists still debate whether citizens are capable of making wise choices through direct elections, and whether referenda on substantive issues should be limited (Kateb 1981); (Bowler et al. 2007); (Gerber 1996).

All of these claims for institutions and rules that effectively - and beneficially - mediate between ignorant citizens and democratic governance find at least some support in the scholarly literature. And all come with the imprimatur of a pungent observation from Jefferson, de Tocqueville, or another equally authoritative commentator. Under what conditions mediating institutions and rules have distorted democratic governance in the face of popular preferences, as in the previous view, or have promoted democratic governance in the face of popular ignorance, as in this view, is a question for which we lack systematic and consensual answers.

\section{Why Is Democracy without an Educated Citizenry Still Valuable?}

The premise of this article, and most of the people quoted herein, is that democracies thrive best - or polyarchies edge toward being democracies - if citizens have a broad education and some level of political knowledge. Education is associated with tolerance, support for rights, civic engagement; political knowledge is important for prospective voting and preferable for retrospective voting.

These are empirical claims with strong historical backing. But the paradox that democratization involves extending the franchise to those least cognitively prepared to be good democratic citizens has a normative as well as empirical edge. Thus the fourth and fifth responses to the paradox are more directly about values than are the first three.

Democracies Do Not Primarily Need a Knowledgeable Citizenry: This set of responses to the paradox simply rejects it. The basic claim here focuses not on measurement error, category mistake, or unit of analysis but rather on disagreement: a democracy does not need, or does not primarily need, a highly educated citizenry in order to function well.

The most interesting feature of this set of arguments is that different versions tend in opposite ideological directions. In the 1950s and later, some relatively conservative political scientists argued that having some portion of the citizenry be disengaged and even ignorant is necessary for maintaining a democracy; otherwise the stakes would be too high in each election. If everyone was passionately and knowledgeably engaged with the issues, the losing party would not grant legitimacy to electoral results or to controversial legislative or judicial decisions, and that would threaten the existence of the state itself. As Bernard Berelson and his colleagues put it, "the apathetic segment of America probably has helped to hold the system together and cushioned the shock of disagreement, adjustment, and change" (Berelson et al. 1954): 322). After all, democratic participation is hard and often unrewarding work, especially if one invests time and energy in learning about electoral or policy choices (Allen 2006); in this view, a democracy needs the apathetic ignorant to balance the passionate experts.

Extending this argument beyond these authors' claims, one can speculate that expanding the electorate to include relatively uninformed new voters provides a constantly renewing disengaged "cushion" for democratic decision-making. Such a cushion may be especially important in eras when technology dramatically increases people's capacity to communicate and be physically mobile - with the development of cities, telegraphs, and trains before the Civil War, 
or telephones and cars in the early twentieth century, or cell phones and the Internet in the early twenty-first century. In this view, pace Jefferson, at least part of the voting public should remain ignorant if the nation is to be free.

A different political valence is expressed by those who see the assertion of a strong link between democracy and knowledgeable citizens as too much focused on cognitions. Democracy is not a graduate seminar, according to critics of the deliberative democrats (Gutmann and Thompson 2004); (Macedo 1999); excessive focus on deliberation may actually detract from democratic politics. As Michael Walzer points out, political activities include not only deliberation but also educating, organizing, mobilizing, demonstrating, lobbying, campaigning, fund-raising, and making decisions (Walzer 1999). Many of these activities require intensity and commitment, but not necessarily knowledge or political sophistication. One can add other noncognitive political acts to Walzer's list: "We would almost certainly wish to question the role in a democratic society of what a good many people would insist on calling 'knowledge.' What, for example, about divine revelation? Our democracy protects the right of people to believe in divine revelation and to regard that revelation as knowledge" (Randel 2008): 9). Or what about group identity or solidarity (Shelby 2005) or ideological comradeship (Walzer 1970)? Perhaps emotions drive voters' choices more than information does (Marcus et al. 2000); (Brader 2005). Even the supreme rationalist James Madison argued that we must rely on citizens' public virtue -- not only on their understanding or attention to interests -- to sustain democratic governance:

As there is a degree of depravity in mankind which requires a certain degree of circumspection and distrust: So there are other qualities in human nature, which justify a certain portion of esteem and confidence. Republican government presupposes the existence of these qualities in a higher degree than any other form. Were the pictures which have been drawn by the political jealousy of some among us, faithful likenesses of the human character, the inference would be that there is not sufficient virtue among men for self-government (Hamilton et al. 1961 (1787)): 378).

In short, ignorance may threaten free government as Jefferson warned, but knowledge is not sufficient and may not even be necessary to maintain a democracy.

Democracy Offers Benefits that Outweigh the Costs of Citizens' Ignorance: The final set of responses to the paradox weighs the anxiety that it expresses against the virtues of democracy, and subsequently sets it aside. The basic claim here focuses not on measurement error, category mistake, unit of analysis, or disagreement but rather on a balancing act. That is, there are indeed costs to continually expanding the franchise to bring in those least cognitively prepared to participate in a democratic polity - but the benefits of democratization outweigh those costs.

Probably every reader, like the writer, shares that view, so I can explicate it briefly. Obtaining the right to participate in democratic governance is a sign of respect, dignity, autonomy, and control for individuals and perhaps for the group they represent; that is why so many people fought for so long to ensure that women and African Americans could not participate. A reader of an earlier version of this article elegantly articulated other virtues of democratic expansion: abstract justice, a desire to purify politics in moral or religious terms, fear of social unrest if dissatisfied people have no legitimate channel to express grievances, provision of an arena to develop organizational capacities and promote civic virtue, and belief that each person is the best expositor of his or her own interests. There may be other reasons, but the point should be clear. Even if voters know too little to make the choices that they would make with more knowledge, enabling them to participate creates a better government and better society than prohibiting them from doing so.

\section{Conclusion}


It is, of course, possible to understand the set of changes in the suffrage as a series of discrete, contingent events. Black men attained the vote because the North won the Civil War; eighteenyear-olds were enfranchised because of tensions over the Vietnam War; the poll tax was struck down because a particular Justice made a particular argument, and so on. After all, each change occurred in unique circumstances and some actually reversed the movement toward greater democratization. However, purely contingent explanations are analytically unsatisfying to the social scientist, and do not account for the fact that most changes in the suffrage over 200 years in the United States (and other countries) have added voters who were below the median voter's level of education or conventional political knowledge. Participants generally recognized that fact but acted anyway, despite everyone's agreement that democracy requires an educated citizenry. Why is that the case?

In answer, I have offered five sets of explanations, each with distinct subsets. Three responded to the historical claim about how democracies actually develop, and two responded to the normative hint that expansion of the franchise might be a mistake. Some of these explanations can happily co-exist, for example the claim that citizens use heuristics to substitute for detailed knowledge and the claim that institutions such as political parties or media can substitute for citizens' knowledge. Others are mutually contradictory, such as the claim that citizens are not too ignorant to maintain a functioning democracy and the claim that citizens are too ignorant even to recognize that an apparent democracy is not genuine.

I am not sure that the empirical sets of explanations can be rigorously tested, especially across a broad sweep of history of the United States or some other country. But it would be useful to do so in order to best position ourselves to deal with the inevitable next set of claimants to democratic standing. Western democracies' next great challenge in this regard is the incorporation of undocumented immigrants, or legal immigrants for that matter, from poor countries with inadequate education systems. In the United States, about a third of adult immigrants have no more than a primary school education; the comparable figures in Germany are almost two-fifths and in France, over three-fifths. ${ }^{15}$ Many immigrants do not speak the host country language until they have lived there for many years, and few have been socialized into the host country's basic political knowledge such as the structure of governance or the usual valence of the political parties. Can and should these immigrants become voting members of their new country? In my view, the answer is "yes," but that is, to put it mildly, a controversial stance. It seems ironic to pit Thomas Jefferson against an impulse to further democratization, but that may be the choice that western democracies once again face.

\section{References}

Aldrich, John. 1995. Why Parties?: The Origin and Transformation of Political Parties in America. Chicago IL: University of Chicago Press.

Allen, Danielle. 2006. Talking to Strangers: Anxieties of Citizenship since Brown v. Board of Education. Chicago IL: University of Chicago Press.

Althaus, Scott. 2003. Collective Preferences in Democratic Politics: Opinion Surveys and the Will of the People. New York: Cambridge University Press.

Alvarez, Michael and John Brehm. 2002. Hard Choices, Easy Answers: Values, Information, and American Public Opinion. Princeton NJ: Princeton University Press.

American Civil Liberties Union. 2008. Breaking Barriers to the Ballot Box: Felon Enfranchisement Toolkit. New York: ACLU, Racial Justice Program.

\footnotetext{
${ }^{15} \mathrm{http} / / / \mathrm{www} . c e n s u s . g o v /$ population/www/socdemo/foreign/acst2.html, Table 2.5a
} European Union Labor Force Survey (data provided by Eurostat) 
Barro, Robert and Jong-Wha Lee. 2001. "International Data on Educational Attainment: Updates and Implications." Oxford Economic Papers. 3 (xx): 541-63.

Bartels, Larry. 1996. "Uninformed Votes: Information Effects in Presidential Elections." American Journal of Political Science. 40 (1): 194-230.

---. 2008. Unequal Democracy: The Political Economy of the New Gilded Age. Princeton NJ: Princeton University Press.

Bennett, Stephen. 1996. "'Know-Nothings' Revisited Again." Political Behavior. 15 (3): 219-33.

Berelson, Bernard, Paul Lazarsfeld, and William McPhee. 1954. Voting: A Study of Opinion Formation in a Presidential Campaign. Chicago IL: University of Chicago Press.

Berry, Jeffrey and Clyde Wilcox. 2007. The Interest Group Society, 4th ed. New York: Pearson Longman.

Bone, Hugh and Austin Ranney. 1976. Politics and Voters, 4th ed. New York: McGraw-Hill.

Bose, Christine. 2001. Women in 1900: Gateway to the Political Economy of the 20th Century. Philadelphia PA: Temple University Press.

Boudreau, Cheryl. 2009a. "Closing the Gap: When Do Cues Eliminate Differences between Sophisticated and Unsophisticated Citizens?" Journal of Politics. 71 (3): 964-76.

---. 2009b. "Making Citizens Smart: When Do Institutions Improve Unsophisticated Citizens' Decisions." Political Behavior. 31 (2): 2878-306.

Bowler, Shaun, Todd Donovan, and Jeffrey Karp. 2007. "Enraged or Engaged? Preferences for Direct Citizen Participation in Affluent Democracies." Political Research Quarterly. 60 (3): 351-62.

Brace, Paul and Melinda Hall. 2005. "Is Judicial Federalism Essential to Democracy? State Courts in the Federal System." in The Judicial Branch: Institutions of American Democracy. Kermit Hall and Kevin McGuire, ed. New York: Oxford University Press, 174-99.

Brader, Ted. 2005. "Striking a Responsive Chord: How Political Ads Motivate and Persuade Voters by Appealing to Emotions." American Journal of Political Science. 49 (2): 388405.

Braiker, Brian. 2007. "Dunce-Cap Nation." Newsweek. June 23, n.p. .

Converse, Philip. 1990. "Popular Representation and the Distribution of Information." in Information and Democratic Processes. John Ferejohn and James Kuklinski, ed. Urbana: University of Illinois Press, 369-88.

Dahl, Robert. 1961. Who Governs? New Haven CT: Yale University Press.

---. 1975. Polyarchy: Participation and Opposition, 5th edition. New Haven CT: Yale University Press.

de Tocqueville, Alexis. 1966 (1848). Democracy in America. New York: Harper \& Row.

Delli Carpini, Michael and Scott Keeter. 1996. What Americans Know About Politics and Why It Matters. New Haven CT: Yale University Press.

Dewhurst, J. Frederic, John Coppock, P. Lamartine Yates, and et al. 1961. Europe's Needs and Resources: Trends and Prospects in Eighteen Countries. New York: Twentieth Century Fund.

Dovi, Suzanne. 2007. The Good Representative. Oxford: Blackwell.

Downs, Anthony. 1957. An Economic Theory of Democracy. New York: Harper.

Easterlin, Richard. 1981. "Why Isn't the Whole World Developed?" Journal of Economic History. 41 (1): 1-19.

Fiorina, Morris. 1981. Retrospective Voting in American Elections. New Haven CT: Yale University Press. 
Gelman, Andrew and Gary King. 1993. "Why Are American Presidential Election Campaign Polls So Variable When Votes Are So Predictable?" British Journal of Political Science. 23 (1): 409-51.

Gerber, Elizabeth. 1996. "Legislatures, Initiatives, and Representation: The Effects of State Legislative Institutions on Policy." Political Research Quarterly. 49 (2): 263-86.

Gibson, James and Gregory Caldeira. 2009. "Knowing the Supreme Court? A Reconsideration of Public Ignorance of the High Court." Journal of Politics. 71 (2): 429-41.

Gilens, Martin. 2001. "Political Ignorance and Collective Policy Preferences." American Political Science Review. 95 (2): 379-96.

Goldin, Claudia. 2006. "Education." in Historical Statistics of the United States, Earliest Times to the Present: Millennial Edition. Richard Sutch and Susan Carter, ed. New York: Cambridge University Press, 2:387-2:498.

Goldin, Claudia and Lawrence Katz. 1997. Why the United States Led in Education: Lessons From Secondary School Expansion, 1910 to 1940. Cambridge MA: National Bureau of Economic Research.

Gordon, Stacy and Gary Segura. 1997. "Cross-National Variation in the Political Sophistication of Individuals: Capability or Choice?" Journal of Politics. 59 (1): 126-47.

Graetz, Michael and Ian Shapiro. 2005. Death by a Thousand Cuts: The Fight over Taxing Inherited Wealth. Princeton NJ: Princeton University Press.

Gutmann, Amy and Dennis Thompson. 2004. Why Deliberative Democracy? Princeton NJ: Princeton University Press.

Hacker, Jacob and Paul Pierson. 2005. "Abandoning the Middle: The Bush Tax Cuts and the Limits of Democratic Control." Perspectives on Politics. 3 (1): 33-53.

Halpern, Diane. 1997. "When Students' Conceptual Grasp Clashes With Their Professors'." Chronicle of Higher Education. March 14, B4-B5.

Hamilton, Alexander, John Jay, and James Madison. 1961 (1787). The Federalist, ed. Jacob Cooke. Middletown CT: Wesleyan University Press.

Hochschild, Jennifer. 1981. What's Fair? American Beliefs about Distributive Justice. Cambridge MA: Harvard University Press.

---. 1984. The New American Dilemma: Liberal Democracy and School Desegregation. New Haven CT: Yale University Press.

Hutchings, Vincent. 2003. Public Opinion and Democratic Accountability: How Citizens Learn about Politics. Princeton NJ: Princeton University Press.

Jefferson, Thomas 1903-04. The Writings of Thomas Jefferson, Memorial Edition, 20 Volumes. Washington, D.C: Thomas Jefferson Memorial Association.

Jerit, Jennifer, Jason Barabas, and Toby Bolsen. 2006. "Citizens, Knowledge, and the Information Environment." American Journal of Political Science. 50 (2): 266-82.

Kateb, George. 1981. "The Moral Distinctiveness of Representative Democracy." Ethics. 91 (3): 357-74.

Keyssar, Alexander. 2000. The Right to Vote: The Contested History of Democracy in the United States. New York: Basic Books.

Kinder, Donald and D. Roderick Kiewiet. 1979. "Economic Discontent and Political Behavior." American Journal of Political Science. 23 (3): 495-527.

Kohn, Nina. 2008. "Cognitive Impairment and the Right to Vote: Rethinking the Meaning of Accessible Elections." Canadian Journal of Elder Law. 1 (1): 29-52.

Kuklinski, James and Paul Quirk. 2000. "Reconsidering the Rational Public: Cognition, Heuristics, and Mass Opinion." in Elements of Reason. Arthur Lupia, Matthew McCubbins, and Samuel Popkin, ed. New York: Cambridge University Press, 153-82. 
Kuklinski, James, Paul Quirk, Jennifer Jerit, David Schwieder, and Robert Rich. 1997.

"Misinformation and the Currency of Democratic Citizenship." Journal of Politics. 62 (3): 790-816.

Lau, Richard and David Redlawsk. 2001. "Advantages and Disadvantages of Cognitive Heuristics in Political Decision Making." American Journal of Political Science. 45 (4): 951-71.

Lupia, Arthur, Mathew McCubbins, and Samuel Popkin, ed. 2000. Elements of Reason: Cognition, Choice, and the Bounds of Rationality. New York: Cambridge University Press.

Macedo, Stephen, ed. 1999. Deliberative Politics: Essays on Democracy and Disagreement. New York: Oxford University Press.

Manza, Jeff and Christopher Uggen. 2004. "Punishment and Democracy: Disfranchisement of Nonincarcerated Felons in the United States." Perspectives on Politics. 2 (3): 491-506.

Marcus, George, W. Russell Neuman, and Michael MacKuen. 2000. Affective Intelligence and Political Judgment. Chicago IL: University of Chicago.

Meyer, David, Valerie Jenness, and Helen Ingram, ed. 2005. Routing the Opposition: Social Movements, Public Policy, and Democracy. Minneapolis: University of Minnesota Press.

Mill, John Stuart. 1862. Considerations on Representative Government. New York: Harper \& Brothers.

Mills, Charles. 1997. The Racial Contract. Ithaca NY: Cornell University Press.

Mondak, Jeffery and Belinda Davis. 2001. "Asked and Answered: Knowledge Levels When We Will Not Take 'Don't Know' for an Answer." Political Behavior. 23 (3): 199-224.

National Center For Education Statistics. 2009. Comparative Indicators of Education in the United States and Other G-8 Countries. Washington D.C.: U.S. Department of Education.

Neuman, W. Russell, Marion Just, and Ann Crigler. 1992. Common Knowledge: News and the Construction of Political Meaning. Chicago IL: University of Chicago Press.

Nie, Norman, Jane Junn, and Kenneth Stehlik-Barry. 1996. Education and Democratic Citizenship in America. Chicago IL: University of Chicago Press.

Parenti, Michael. 2007. Democracy for the Few, 8th ed. New York?: Wadsworth

Peterson, Merrill. 1966. Democracy, Liberty and Property; The State Constitutional Conventions of the 1820's. Indianapolis, IN: Bobbs-Merrill Co.

Popkin, Samuel. 1993. "Information Shortcuts and the Reasoning Voter." in Information, Participation, and Choice. Bernard Grofman, ed. Ann Arbor: University of Michigan Press, 17-35.

Prior, Markus. 2005. "News vs. Entertainment: How Increasing Media Choice Widens Gaps in Political Knowledge and Turnout." American Journal of Political Science. 49 (3): 577-92.

Protess, David, Fay Lomax Cook, Thomas Curtin, Margaret Gordon, Donna Leff, Maxwell McCombs, and Peter Miller. 1987. "The Impact of Investigative Reporting on Public Opinion and Policymaking: Targeting Toxic Waste." Public Opinion Quarterly. 51 (2): 166-85.

Randel, Don. 2008. "The Public Good: Knowledge as the Foundation for a Democratic Society." in The Public Good: Knowledge as the Foundation for a Democratic Society. n.a., ed. Cambridge MA: American Academy of Arts and Sciences, 9-13.

Ravitch, Diane and Chester Finn. 1988. What Do Our 17-Year-Olds Know?: A Report on the First National Assessment of History and Literature. New York: Harper \& Row.

Scalia, Laura. 1999. America's Jeffersonian Experiment: Remaking State Constitutions, 1820 1850. DeKalb IL: Northern Illinois University Press.

Schattschneider, E. E. 1942. Party Government. New York: Rinehart. 
--- 1960. The Semi-Sovereign People: A Realist's View of Democracy in America. New York: Holt, Rinehart and Winston.

Schlozman, Kay, Sidney Verba, Henry Brady, Philip Jones, and Traci Burch. 2008. Who Sings in the Heavenly Chorus? Political Inequality and the Pressure System. American Political Science Association, Boston MA: August 28-31.

Schudson, Michael. 1998. The Good Citizen: A History of American Civic Life. New York: Free Press.

Schumpeter, Joseph. 1942. Capitalism, Socialism, and Democracy. New York: Harper \& Brothers.

Shelby, Tommie. 2005. We Who Are Dark: The Philosophical Foundations of Black Solidarity. Cambridge, MA: Harvard University Press.

Smalley, Suzanne and Sarah Kliff. 2008. "Just How Low Will They Go." Newsweek. June 9, 3435.

Somin, Ilya. 2004. "Political Ignorance and the Countermajoritarian Difficulty:A New Perspective on the Central Obsession of Constitutional Theory." Iowa Law Review. 89 (4): 1287-371.

Street, John. 2001. Mass Media, Politics, and Democracy. New York: Palgrave.

Sunstein, Cass. 2005. "Judges and Democracy: The Changing Role of the United States Supreme Court." in The Judicial Branch: Institutions of American Democracy. Kermit Hall and Kevin McGuire, ed. New York: Oxford University Press, 32-59.

Walzer, Michael. 1970. Obligations : Essays on Disobedience, War, and Citizenship. Cambridge MA: Harvard University Press.

---. 1999. "Deliberation and What Else?" in Deliberative Politics: Essays on Democracy and Disagreement. Stephen Macedo, ed. New York: Oxford University Press, 58-69.

Whittington, Keith. 2007. Political Foundations of Judicial Supremacy: The Presidency, the Supreme Court, and Constitutional Leadership in U.S. History. Princeton NJ: Princeton University Press.

Wolak, Jennifer. 2009. "The Consequences of Concurrent Campaigns for Citizen Knowledge of Congressional Candidates." Political Behavior. 31 (2): 211-29.

Woodson, Carter. 1933. The Mis-Education of the Negro Washington D.C.: Associated Publishers.

Zaller, John. 1992. The Nature and Origins of Mass Opinion. New York: Cambridge University Press. 